\title{
Polynesian Language
}

National Cancer Institute

\section{Source}

National Cancer Institute. Polynesian Language. NCI Thesaurus. Code C161903.

A language family spoken in geographical Polynesia and on a patchwork of outliers from south central Micronesia to small islands off the northeast of the larger islands of the southeast Solomon Islands and sprinkled through Vanuatu. 